\title{
An Integral Sign Conductor in the Frontal Himalaya Region and Its Tectonic Interpretation
}

\author{
C. D. REDDY
}

Indian Institute of Geomagnetism, Colaba, Bombay 400 005, India

(Received November 7, 1996; Revised May 28, 1997; Accepted August 19, 1997)

\begin{abstract}
A 3-D thin sheet model is developed synthesizing the data from different small array studies in the frontal Himalaya region. Most of the regional anomaly is simulated by a single highly conducting zone approximating an integral sign in shape $(f)$. The integral sign conductor (ISC) is basically an extension of Trans-Himalayan Conductor at the northern and southern ends towards east and west respectively. The conductance map indicates that the crust beneath the Indo-Gangetic Plains (IGP) lying on the western side of the ISC is electrically one order more conducting than on the eastern part.

The synthesis of many geophysical signatures has permitted to infer that the Indian shield contiguous to the frontal Himalaya is mosaic of two crustal blocks of contrasting geophysical properties. In such tectonic scenario, the ISC is seen as a northeast continuation of the Aravalli range beneath the IGP and is interpreted to represent accretion zone resulting from the collision or underthrusting of the eastern crustal block beneath the western block. The clustering of epicenters along the ISC marks the continued activation of this ancient structure.
\end{abstract}

\section{Introduction}

Himalaya orogeny is believed to be manifestation of collision between Indian and Eurasian plates. Continued underthrusting of the Indian plate under Eurasian plate has greatly deformed the frontal Himalaya collision zone. Thus, this zone with subduction, obduction, mega fractures, faults, folds together with adjoining Indo-Gangetic plains (IGP) forms a gigantic laboratory and testing ground for continent to continent collision concepts. Figure 1 gives the general geotectonics of the Himalaya and adjacent regions. Some of the papers which provide geo-seismotectonics of the Himalaya collision zone are Powell and Conaghan (1973); Lefort (1975); Hirn et al. (1984); Molnar (1984); Ni and Barazangi (1984). Tectonic, thermomechanical, hydrothermal, chemical, geomorphological and seismic process are all operative in this region and involve significant fluid, mass and heat transportation. The conductivity, in addition to being determined by chemical constituents, is extremely sensitive to most of the above processes and determining the conductivity distribution considered to be vital for understanding the intricacies of operative geodynamic processes in the frontal Himalaya region.

Towards this, number of magnetovariational (MV) and magnetotelluric (MT) studies have been carried out in the past one and half decades in frontal Himalaya and contiguous regions, which resulted in delineation of many conductive zones. Some of the important findings from these earlier works have been summarized by Arora (1990) and Reddy (1994). The extensive data generated from these arrays provide necessary data inputs to develop a regional conductivity model. Towards this, the data from the North West India (1979), Garhwal (1985), Kangra (1985), Ganga-Yamuna Valley (1987-91) and UP-West Nepal Border (1993) arrays have been used. These localised and regional arrays provided independent constraints on the tectonics of the frontal Himalaya and adjacent Indian shield. For more details of these independent array studies one can refer to Arora and Singh (1992); Arora (1993); Reddy (1994). 


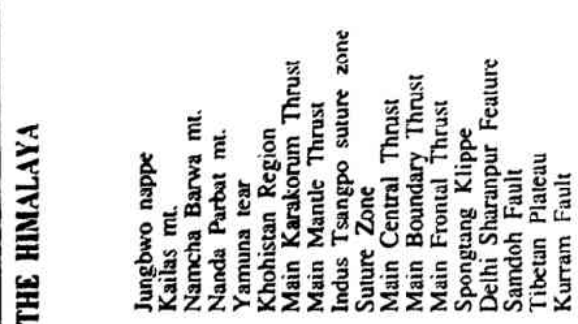

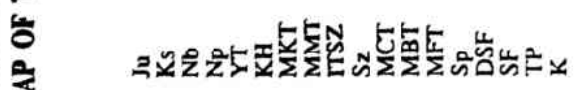 \\ 2

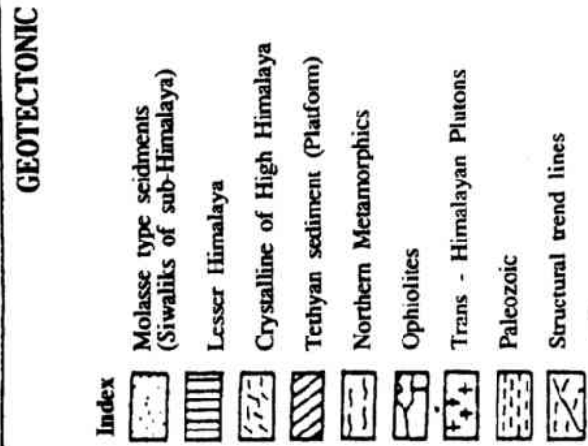

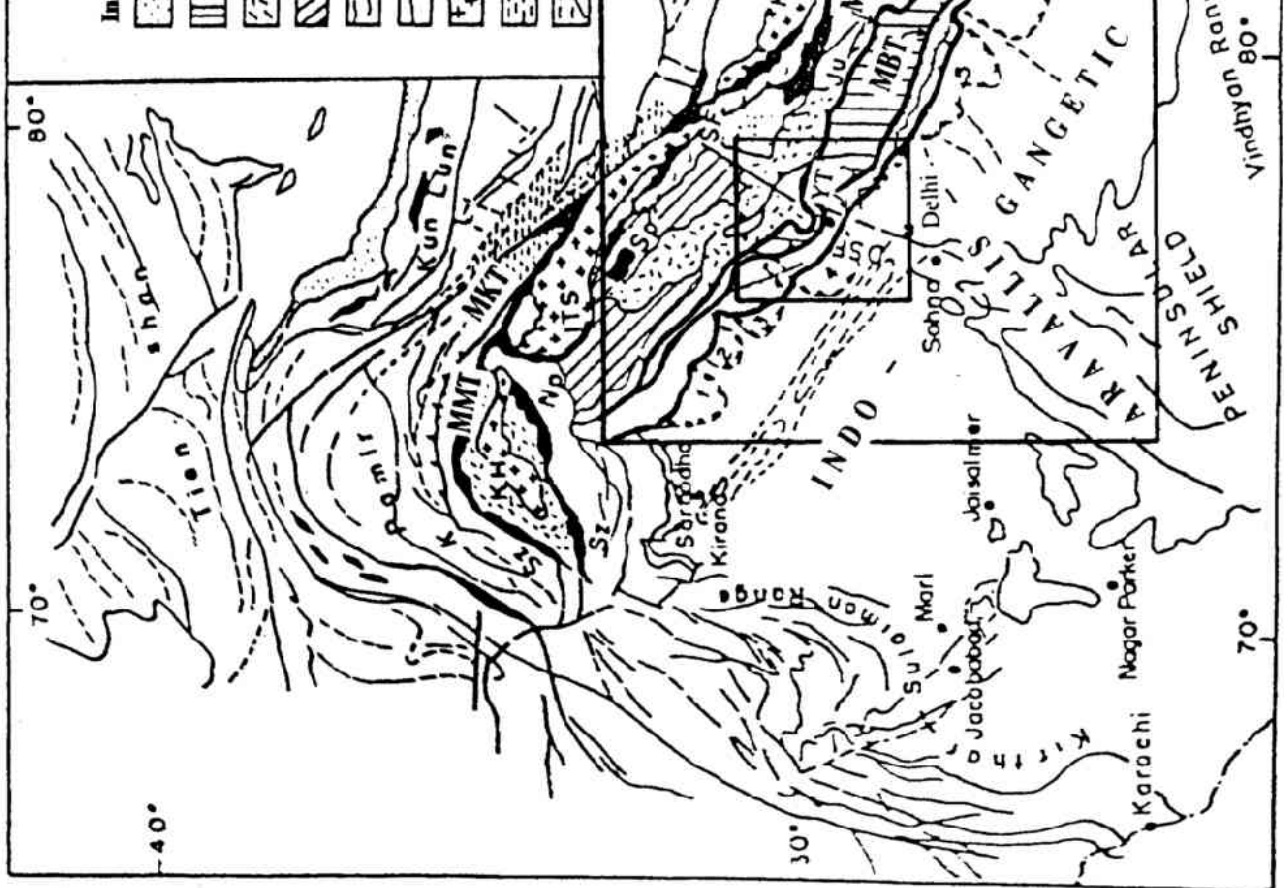

断峦

ํํㄹ

昍题

능

분 명

형

䨔需

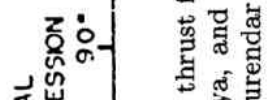

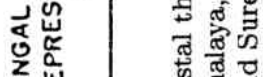

营 สี

I

苛若

봉

害焉

음

芒运

$\leqq$ 의

낭

旨

ธี่

bु의

卷

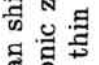

胥

范焉

范

สี ฐ

需究尔

自送承

田

동 응

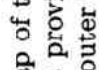

密骂

光

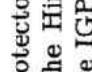

速 
The composite induction arrow map corresponding to transfer functions for period 60 minutes is shown in Fig. 2. As evident from this map, large number of induction anomalies with varied orientation and extent are present. In addition to distinct anomalies related to the Main Frontal Thrust (MFT) and Garhwal Lesser Himalaya Conductivity Anomaly (GLHCA), described in Reddy (1994); Arora and Reddy (1995), the oppositely directed arrows over the part of IGP and lesser Himalaya formed strong evidence for the Trans-Himalayan Conductor (THC) (Lilley et al., 1981; Arora and Mahashabde, 1987). The northward directed arrows at the northern sites of the UP-West Nepal profile suggests the presence of a conducting zone beneath the higher Himalaya (Pandey and Arora, 1997). The THC and some other anomalies whose induction response were found to be compatible with 2-D structure, have already been modelled using 2-D formulation earlier (Arora, 1990; Reddy and Arora, 1993). However, 2-D modelling is not

\section{REN VETTORS \\ PERD $=$ EO.0 WIN}

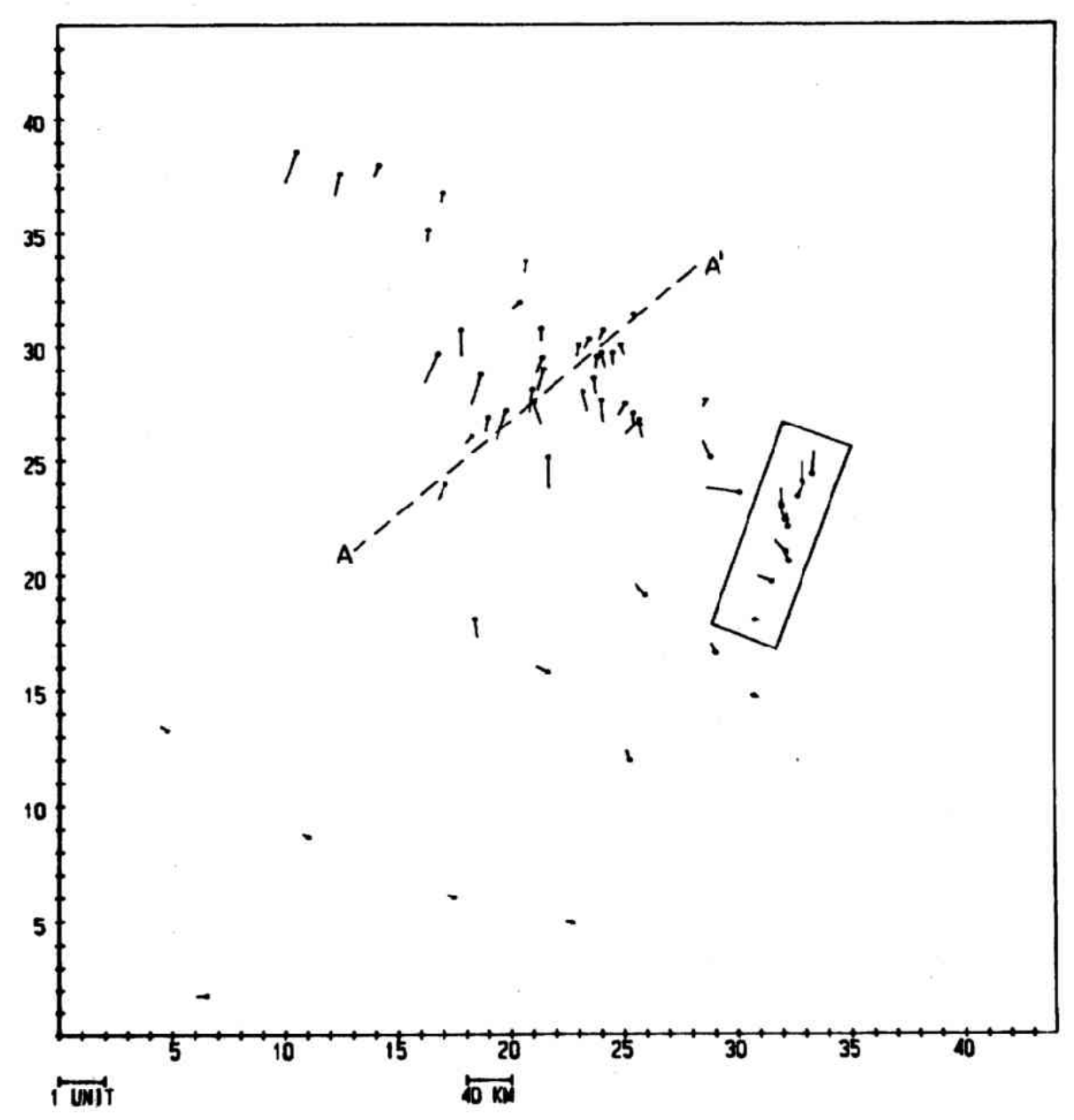

Fig. 2. Real induction arrows of observed EM response for the period $60 \mathrm{~min}$, obtained after combining data from different array studies in the region. The arrows enclosed in the rectangular block correspond to UP-West Nepal Border profile. The profile $\mathrm{AA}^{\prime}$ is referred in Fig. 6. 
sufficient to explain 3-D conductivity distribution in the region. As the 3-D modelling is unwieldy, thin-sheet approximation (3-D) of variable conductance is considered suitable to provide unified picture of near surface 3-D conductivity distribution. This paper describes a 3-D thin sheet model which has been developed and provides tectonic interpretation of the ISC which is considered to be the most important conductivity anomaly in the study region.

\section{Thin Sheet Model for Frontal Himalaya}

For the development of thin-sheet model, the formulation of Vasseur and Weidelt (1977) is employed. This formulation requires that the anomalous domain (region), should be surrounded by a region of normal structure. As the present area is bounded by different tectonic environments, to minimize the effect of artificially confining the anomalous domain by normal structure, the terminal boundaries have to be sufficiently far from the actual observational domain. Compliance of this numerical constraints was achieved by including a very large geographic region. The large rectangular block in the Fig. 1 shows the extent of region considered for thin-sheet modelling. For the computational purposes, the area of the rectangular block was divided into a square grid of $40 \times 40$ with cell spacing of $20 \mathrm{~km}$.

Though, the formulation adopted permits incorporation of the thin-sheet containing the anomaly at any depth, a thin-sheet of variable conductance with an equivalent thickness of 6 $\mathrm{km}$ is considered to overlie a four layered structure as shown in Fig. 3. The first layer with 10 $\mathrm{km}$ thick is considered to consist the mid-crustal layer with a conductivity of $0.1 \mathrm{Sm}^{-1}$ and the second layer with $30 \mathrm{~km}$ thickness represents the resistive lower crust with a conductivity of 0.001 $\mathrm{Sm}^{-1}$. The third layer is $40 \mathrm{~km}$ thick with a conductivity of $0.0005 \mathrm{Sm}^{-1}$ and the fourth is an underlying half-space with a conductivity of $0.008 \mathrm{Sm}^{-1}$. The above conductivity values have been assigned on the basis of MV and MT studies and known geotectonics of the region (Powell and Conaghan, 1973; Lefort, 1975; Agarwal, 1983; Ni and Barazangi, 1984; Hirn et al., 1984; Molnar, 1984; Reddy, 1994; Gupta et al., 1997) The normal structure outside the anomalous domain is represented by a medium of $15 \mathrm{~S}$, equivalent to a material of $400 \mathrm{Ohm}-\mathrm{m}$.

The initial assignment of conductance to each cell was based on the 2-D electrical resistivity model developed by (Reddy and Arora, 1993) and lithological character of the rock types exposed at the surface. Care was also exercised that conductances assigned were such that the stipulated thin-sheet conditions (Weaver, 1982) satisfied in each cell of the anomalous domain. The conductance description map which reproduced the major features of the observed induction pattern is given in Fig. 3 in coded form, which are explained on the right corner of the map. Supplementing Fig. 3, perspective view of the conductance map is given in Fig. 4.

In the numerical computation for a given conductance distribution, the values of the three magnetic field components $H_{x}, H_{y}$ and $H_{z}$ for two polarizations of the normal horizontal magnetic field were calculated. These were then combined in the conventional manner to yield induction arrows at all grid points at the surface. The computations have been carried out for a period of $60 \mathrm{~min}$ as the observed response, in statistical sense, is best resolved at this period. The resulting real induction arrow pattern corresponding to the conductance map is shown in Fig. 5 . The comparison of the observed and calculated pattern is carried out by directly superposing the observed arrow pattern (without arrow heads) on calculated arrow (with arrow heads) pattern. For better qualitative comparison, the computed responses of 3-D thin sheet as well as 2-D (Reddy and Arora, 1993) models are compared with the observed response along a profile $\mathrm{AA}^{\prime}$ (Fig. 2) and presented in Fig. 6 .

Most of the induction response is simulated by a single highly conducting zone approximating an integral sign $\left(\int\right)$ in shape and referred to as Integral Sign Conductor (ISC), conductivity contrast across MFT and furrowed conducting zones parallel to MFT. This paper mostly confines to only ISC and provide its tectonic interpretations. 


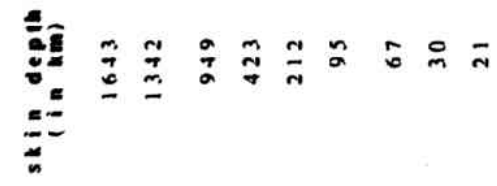

望 \& \& \&

䒹 距
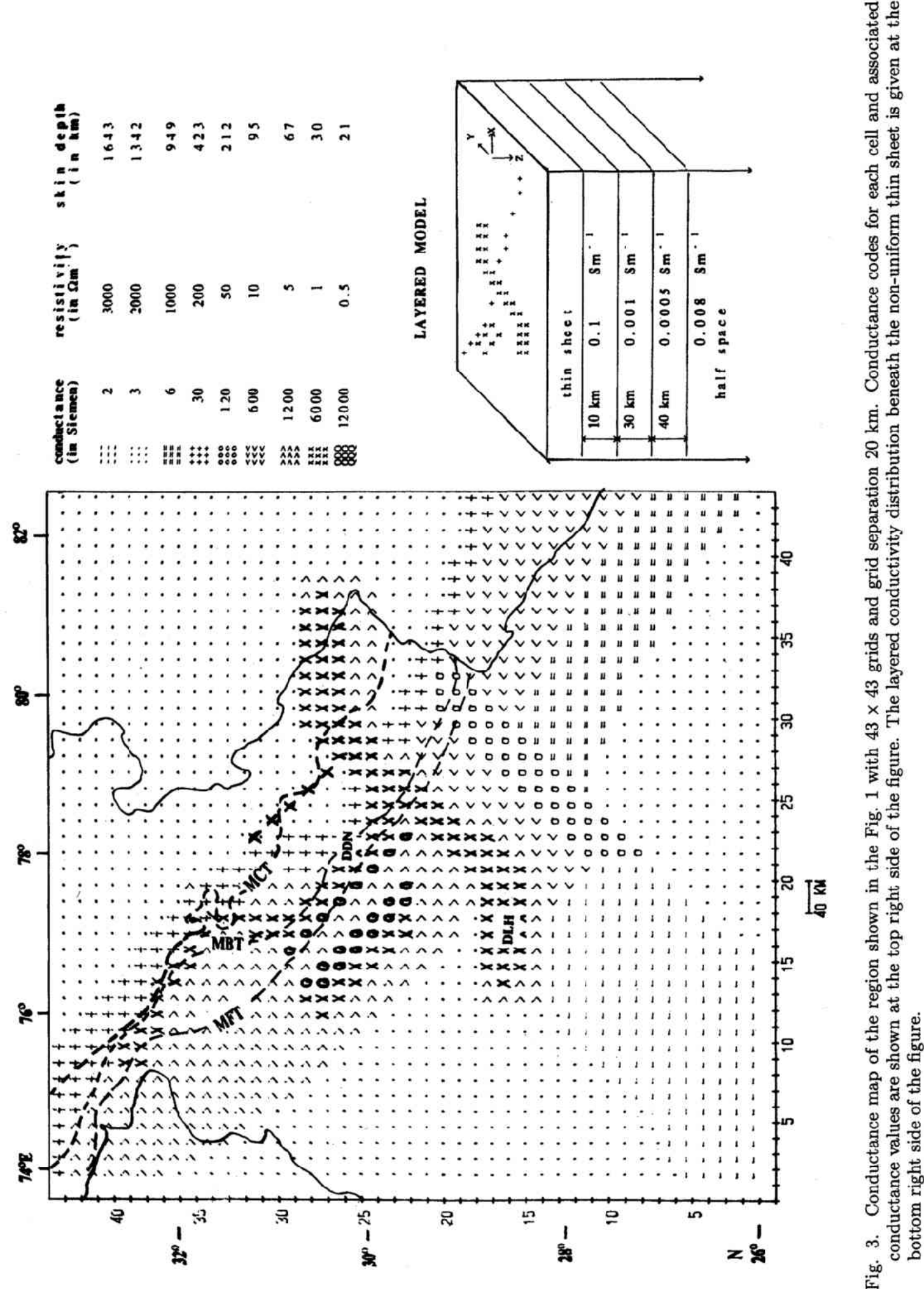


\section{CONDUCTANCE MAP}

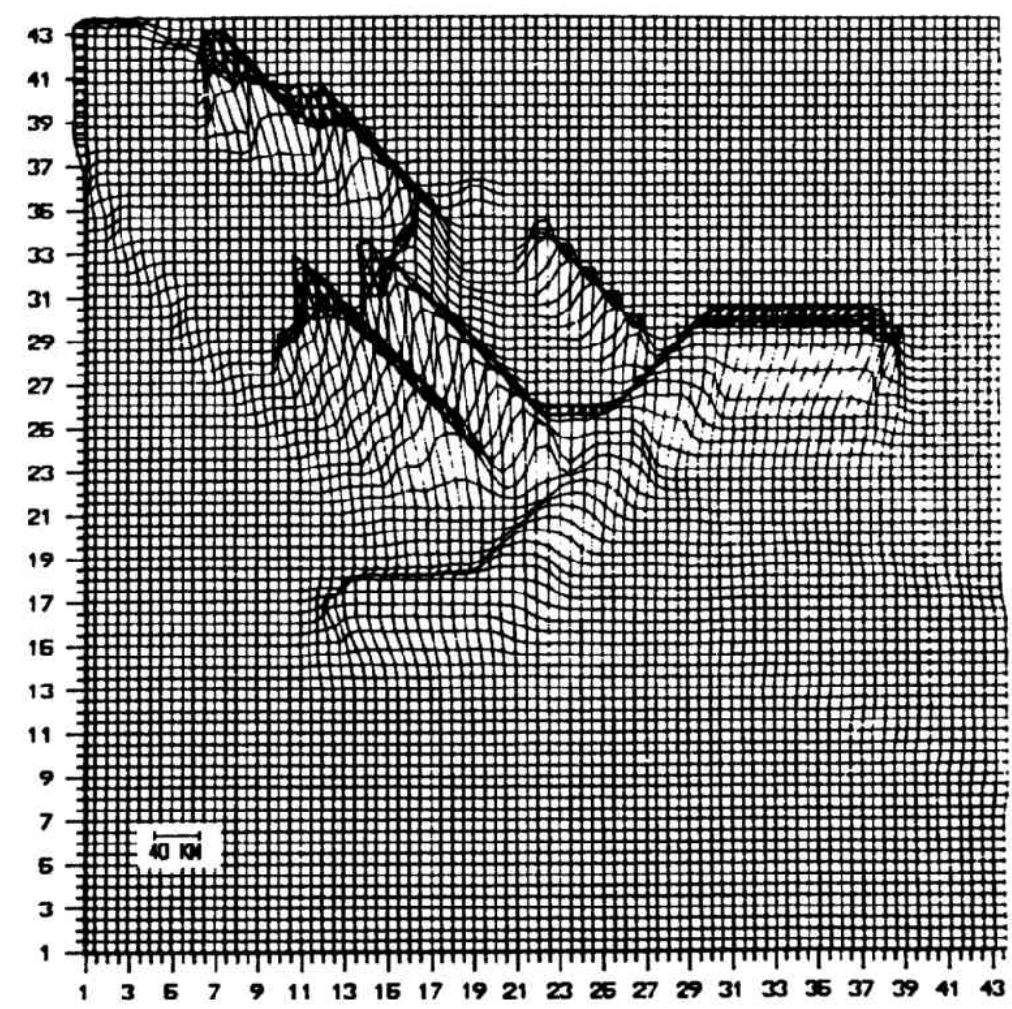

Fig. 4. Perspective view of the conductance map shown in Fig. 3. The ISC zone signifies eastward and westward extension of the THC at its top and bottom respectively. Also note the furrowed-type conducting zones parallel to the trend of the collision zone.

\section{Tectonic Interpretation of ISC}

The ISC can be best visualized as an eastward extension of the THC at the northern end and westward extension on its southern extremity. The THC itself is a dominant conductive structure emerging out of the Himalaya into the IGP, following the Aravalli trend, is one of the major continental induction anomalies mapped by the earlier EM induction studies (Lilley et al., 1981; Arora and Mahashabde, 1987). Its structural configuration, possible causative mechanism and its geological and tectonic significance are given by Arora (1990). The MT data from thirteen stations placed along the Mohand to Ramnagar profile have independently corroborated the existence of the THC (ISC) at a depth of $10 \mathrm{~km}$ with a overall width of 50-60 km (Gupta et al., 1994). The set of induction arrows enclosed in the rectangular box in the Fig. 2 (which point towards north and display clockwise swing as the stations are approached from south to north) together with the induction arrows north of IGP strongly support the northern continuation of the THC towards east direction. However, its extension towards west at the southern end of THC is poorly constrained.

The conductance map obtained by 3-D thin sheet modelling indicates that the crust beneath the IGP lying on the western side of the ISC is electrically one order more conducting than on the eastern side of the ISC. The physical evidence that the induction arrows from the U.P.-West 


\section{REAL VECTORS \\ PERD $=60.0$ MIN \\ HI118}

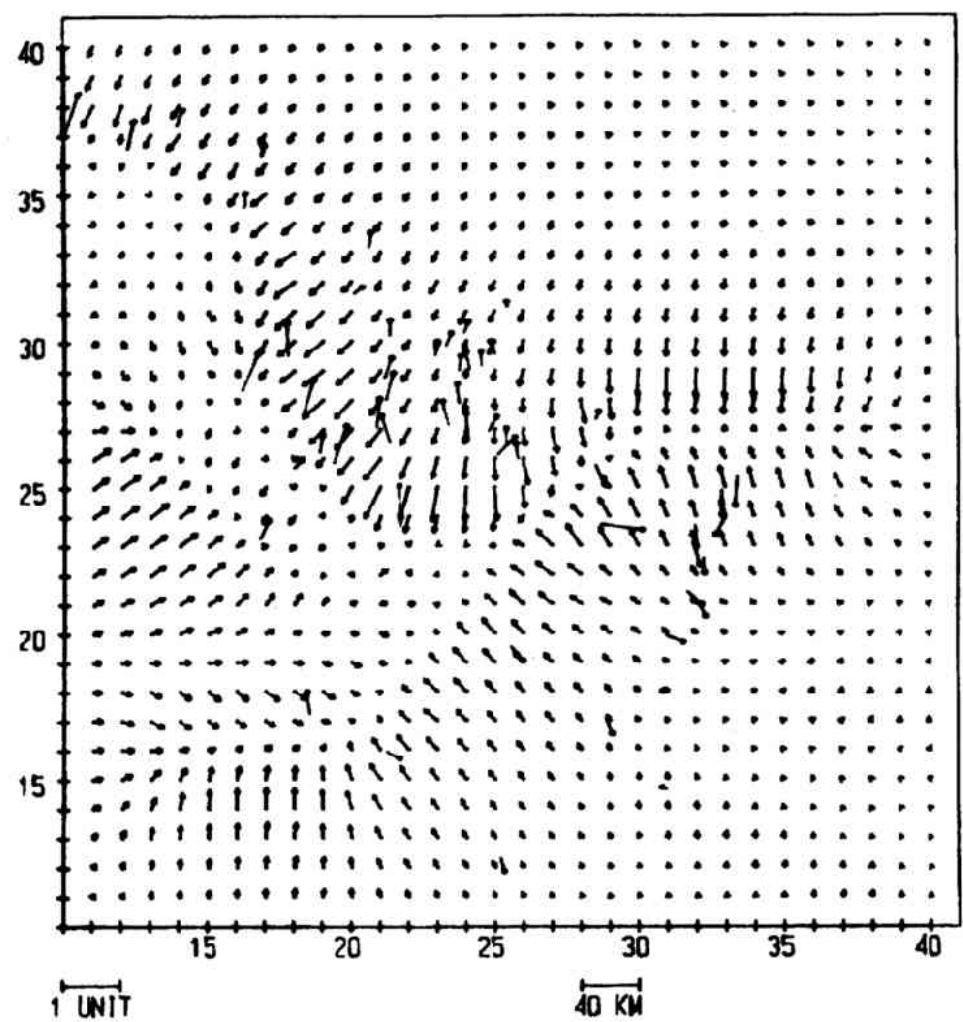

Fig. 5. Comparison of observed (without arrow head) and computed (with arrow head) real induction arrows at the recording sites for a period of $60 \mathrm{~min}$.

Nepal survey point away from the IGP towards the higher Himalaya, in contrast to the pattern in the IGP east of ISC. This set of induction arrows are enclosed by a rectangular block in Fig. 2 .

The conductance map in Figs. 3 and 4 indicates that the region west of ISC has more complex electrical conductivity distribution than that of the east. On the west, prominent induction anomalies include two high conducting zones parallel to the strike of the Himalaya, which correspond to the two hump-shaped anomalies in 2-D model developed by Reddy and Arora (1993). These two conducting zones together with a localized and narrow conducting zone coincident with the GLHSB (Reddy and Arora, 1992a, b) collectively seen as furrowed conducting zones running approximately parallel to the MFT and MCT (Fig. 4).

It is interesting to see the longitudinal inequalities in lithological characteristics of the crust beneath the western and eastern parts of IGP separated by ISC. The characteristic shear wave velocity structure (Chun, 1986) for eastern and western IGP, led Chun (1986) to suggest that the crustal structure beneath the western IGP (w.r.t. ISC) is a strong reminiscent of certain oceanic plateaus. The spatial behaviour of Bouguer anomalies along the four profiles (Das et al., 1979) running across the Himalaya along different longitudinal sectors (incidentally, two profiles lie on the west of ISC and other two east of ISC) provide new perspective in elucidating the lateral inequalities of the Himalaya and the adjoining Indian shield. It is postulated that the 


\section{Quadrature}
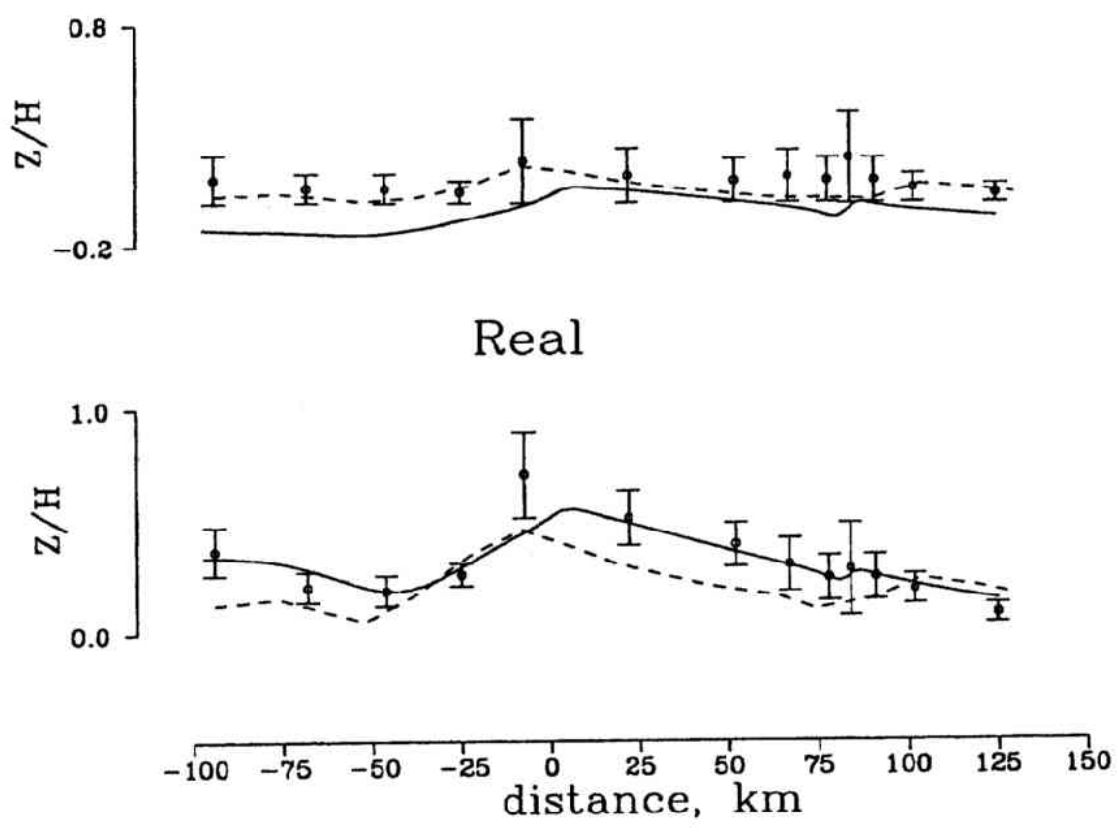

Fig. 6. Real and quadrature response along $\mathbf{A A}^{\prime}$ (Fig. 2) obtained from 3-D thin sheet modelling (dashed) and 2-D modelling (solid line, Reddy and Arora, 1993). Open circles indicate the observed response for period of $60 \mathrm{~min}$. Vertical bars denote 1 sd error associated with the observed response at the respective sites.

underthrusting of Indian plate beneath the Eurasian plate on the western side of ISC is different from that of eastern side. Some other geological and geophysical signatures supporting the eastwest asymmetry are presented in Table 1.

The synthesis of these geophysical signatures has permitted to infer that the Indian shield contiguous to the frontal Himalaya is mosaic of two crustal blocks (Tras-Aravalli and Bundelkhand) of contrasting geophysical properties. In such a tectonic scenario, the ISC, seen as a northeast continuation of the Aravalli range beneath the IGP, is interpreted to represent accretion zone between two blocks of different geophysical characters. Based on an asymmetric domal upwarp in middle crust (Arora, 1990), it is considered that this accretion zone has been rejuvenated in response to Quarternary tectonism arising due to the forces generated from the locking of the Indian-Eurasian plates since early Pleistocene (Arora, 1993). The fluids released during the process of metamorphism or the invasion of mantle fluids as a consequence of collision and attendant crustal interstacking are the most likely causes of enhanced conductivity (Jones, 1993).

\section{Conclusions}

3-D thin-sheet model has been developed for the frontal Himalaya region by integrating the data from many independent MV surveys. The most striking feature of the model is, a highly conducting zone approximating an integral sign $\left(\int\right)$ in shape and referred to as Integral Sign Conductor (ISC). The ISC considered to be extension of THC towards east and west at its northern and southern ends respectively. Synthesis of many geophysical signatures has permitted to infer that the Indian shield contiguous to the frontal Himalaya region is mosaic of two crustal 
Table 1. Geological/Geophysical signatures supporting longitudinal inequalities in the character of the crust beneath the IGP.

\begin{tabular}{|l|l|l|l|}
\hline $\begin{array}{l}\text { Geophysical } \\
\text { parameter }\end{array}$ & $\begin{array}{l}\text { IGP west of } \\
\text { ISC }\end{array}$ & $\begin{array}{l}\text { IGP east of } \\
\text { ISC }\end{array}$ & References \\
\hline Conductivity & $\begin{array}{l}\text { More } \\
\text { conducting }\end{array}$ & $\begin{array}{l}\text { Less } \\
\text { conducting }\end{array}$ & Reddy (1994) \\
\hline Density & High & Normal & Sivaji et al. (1992) \\
\hline Crustal type & Oceanic & Continental & Chun (1986) \\
\hline $\begin{array}{l}\text { Seismic wave } \\
\text { velocity structure }\end{array}$ & High velocity & Normal & Chun (1986) \\
\hline $\begin{array}{l}\text { Slip vector of } \\
\text { earthquake }\end{array}$ & $20^{\circ}-25^{\circ}$ & $10^{\circ}$ & $\begin{array}{l}\text { Ni and Barazangi (1984) } \\
\text { Molnar (1984) }\end{array}$ \\
\hline Crustal shortening & Less & More & Mattauer (1986) \\
\hline $\begin{array}{l}\text { Anomalies in the } \\
\text { arrival of P-waves }\end{array}$ & $\begin{array}{l}\text { Negative } \\
\text { residual }\end{array}$ & $\begin{array}{l}\text { No significant } \\
\text { anomalies }\end{array}$ & $\begin{array}{l}\text { Chander (1988) } \\
\text { Mohan and Rai (1993) }\end{array}$ \\
\hline $\begin{array}{l}\text { Basement } \\
\text { topography }\end{array}$ & Smooth & $\begin{array}{l}\text { Rugged,highly } \\
\text { undulating }\end{array}$ & $\begin{array}{l}\text { Karunakaran and } \\
\text { Ranga Rao (1979) }\end{array}$ \\
\hline $\begin{array}{l}\text { Latitudinal extent } \\
\text { of the Siwalik }\end{array}$ & Broad & Narrow & $\begin{array}{l}\text { Eremenko and } \\
\text { Negi (1968) }\end{array}$ \\
\hline
\end{tabular}

blocks of contrasting geophysical properties and the ISC is interpreted to represent demarcating accretion zone. The high conductivity of this zone may be associated to the presence of mantle fluids as a consequence of interstacking of eastern and western crustal blocks. The clustering of epicenters along this conducting zone implies the continued activation of this process.

A part of this work has been financially supported by Department of Science and Technology (DST), Government of India. The financial support is gratefully acknowledged. The author expresses his gratitude to B.R. Arora for his guidance and encouragement.

\section{REFERENCES}

Agarwal, A. K., Analysis of transient magnetic variations: Case studies for sub-surface structure and source field characteristics, Ph.D. Thesis, submitted to Bombay University, Bombay, India, 1983.

Arora, B. R., Magnetometer array studies in India: Present status, data interpretation and assessment of numerical modelling results, Proc. Ind. Acad. Sci. (Earth Planet. Sci.), 99, 693-716, 1990.

Arora, B. R., Implications of electrical conductivity structures in the tectonic framework of Northwest India, Current Science, 64, 848-855, 1993.

Arora, B. R. and M. V. Mahashabde, A transverse conductive structure in the northwest Himalaya, Phys. Earth Planet. Inter., 45, 119-127, 1987.

Arora, B. R. and C. D. Reddy, Deep conductive structures of the frontal belt of the Garhwal Himalaya and their seismotectonic significance, Mem. J. Geol. Soc. India, 30, 109-124, 1995.

Arora, B. R. and B. P. Singh, Geomagnetic and geoelectric investigations for the seismicity and seismotectonics of the Himalaya region, Mem. J. Geol. Soc. India, 23, 223-267, 1992.

Chander, R., Estimation of seismic velocity structure in the Garhwal Himalaya using teleseismic P arrival times, Abstract, AEG Seminor, Andhra Univ. Waltair, Nov. 17-19, a-34, 1988.

Chun, K. Y., Crustal block of the western Ganga basin: A fragment of oceanic affinity, Bull. Seismol. Soc. Am., 76(6), 1687-1698, 1986.

Das, D., G. Mehra, K. G. C. Rao, A. L. Roy, and M. S. Narayana, Bouguer, Free-air and magnetic anomalies over north-western Himalayas, The Himalayan Geology Seminar, New Delhi, Geological Survey of India, Miscelaneous Publications, 41, 141-147, 1979.

Eremenko, N. A. and B. S. Negi, Tectonic Map of India, ONGC, Dehra Dun, 1968.

Gupta, G., S. G. Gokarn, and B. P. Singh, Thickness of the Siwalik sediments in the Mohand-Ramnagar region using magnetotelluric studies, Phys. Earth Planet. Inter., 83, 217-224, 1994. 
Gupta, G., C. K. Rao, and S. G. Gokarn, Deep geoelectric structure in the Rohtak region using the magnetotelluric studies, J. Geol. Soc. India, 1997 (in press).

Hirn, A., J. C. Lipini, G. Jobert, M. Sapin, G. Wittlinger, X. Z. Xin, G. E. Yuan, W. X. Jing, T. J. Wen, X. S. Bai, M. R. Pandey, and J. M. Tater, Crustal structure and variability of the Himalayan border of Tibet, Nature, 307, 23-25, 1984.

Jones, A. G., Electromagnetic images of modern and ancient subduction zones, Tectonophysics, 219, 29-45, 1993.

Karunakaran, C. and A. Ranga Rao, Status of exploration for hydrocarbons in the Himalayan region, Proc. Himalayan Geology Seminar, Sec. III, New Delhi. Misc. Pub. Geol. Surv. Ind., 41(5), 1-66, 1979.

Lefort, P., Himalayas: the collided range. Present knowledge of the continental arc, Am. J. Sci., A275, 1-44, 1975.

Lilley, F. E. M., B. P. Singh, B. R. Arora, B. J. Srivastava, N. S. Prasad, and M. N. Sloane, A magnetometer array study in northwest India, Phys. Earth Planet. Inter., 25, 232-240, 1981.

Mattauer, M., Intracontinental Subduction, Crust-Mantle Decollement and Crustal Stacking Wedge in the Himalaya and Other Collision Belts, edited by Coward, M. P. and A. C. Ries, Collision tectonics, special publication of the geological Society, India, 19, 37-50, 1986.

Mohan, G. and S. S. Rai, Critical evaluation and geological correlation of teleseismic phase data from Indian seismological stations, Proc. Indian Acad. Sci. (Earth Planet. Sci.), 101, 387-401, 1993.

Molnar, P., Structure and tectonics of the Himalaya: Constrains and implications of geophysical data, Annual Rev. Earth Planet. Sci., 12, 489-519, 1984.

$\mathrm{Ni}$, J. and M. Barazangi, Seismotectonics of the Himalaya collision zone: Geometry of underthrusting plate beneath the Himalaya, J. Geophys. Res., 89, 1147-1163, 1984.

Pandey, A. and B. R. Arora, Geomagnetic induction anomalies along UP-West Nepal boarder, (under preparation), 1997.

Powell, C. M. and P. Conaghan, Plate tectonics and the Himalayas, Earth Planet. Sci. Let., 20, 1-12, 1973.

Qureshy, M. N. and Surendar Kumar, Isostasy and Neotectonics of the Northwest Himalaya and Foredeep, Memoir J. Geol. Soc. India, 23, 201-222, 1992.

Reddy, C. D., Electromagnetic induction studies in Garhwal Himalaya and adjacent regions, Ph.D. Thesis, submitted to Bombay University, Bombay, India, 1994.

Reddy, C. D. and B. R. Arora, A narrow conductive zone south of the Main Central Thrust of the Garhwal Himalaya, Memoir J. Geol. Soc. India, 24, 121-131, 1992a.

Reddy, C. D. and B. R. Arora, Geomagnetic induction anomalies in the frontal belt of Garhwal Himalaya, Acta Geodaet. Geophys. et Montanist. Acad. Sci. Hung., 27, 19-34, 1992b.

Reddy, C. D. and B. R. Arora, Quantitative interpretation of geomagnetic induction response across the thrust zones of the Himalaya along the Ganga-Yamuna valley, J. Geomag. Geoelectr., 45, 775-785, 1993.

Sivaji, C. H., B. R. Arora, and M. N. Qureshy, An assessment of the nature of the crust under the Himalya collision zone through gravity studies, J. Geol. Soc. India, 24, 103-112, 1992.

Vasseur, G. and P. Weidelt, Bimodal electromagnetic induction in non-uniform thin sheets with an application to the northern Pyrenean induction anomaly, Geophys. J. Roy. Astron. Soc., 51, 669-690, 1977.

Weaver, J. T., Regional induction in Scotland: an example of three-dimensional modelling using the thin sheet approximation, Phys. Earth Planet. Inter., 28, 161-180, 1982. 